Review

\title{
When Boeing is Dreaming - a Review
}

\author{
${ }^{1}$ Relly Victoria Virgil Petrescu, ${ }^{2}$ Raffaella Aversa, ${ }^{3}$ Bilal Akash, ${ }^{4}$ Juan Corchado, \\ ${ }^{2}$ Antonio Apicella and ${ }^{1}$ Florian Ion T. Petrescu \\ ${ }^{I}$ ARoTMM-IFToMM, Bucharest Polytechnic University, Bucharest, (CE), Romania \\ ${ }^{2}$ Advanced Material Lab, Department of Architecture and Industrial Design, \\ Second University of Naples, 81031 Aversa (CE), Italy \\ ${ }^{3}$ Dean of School of Graduate Studies and Research, American University of Ras Al Khaimah, UAE \\ ${ }^{4}$ University of Salamanca, Spain
}

Article history

Received: 17-04-2017

Revised: 09-05-2017

Accepted: 07-07-2017

Corresponding Author: Florian Ion Tiberiu Petrescu ARoTMM-IFToMM, Bucharest Polytechnic University,

Bucharest, (CE), Romania

E-mail: scipub02@gmail.com
Abstract: Boeing is an aeronautical and aerospace manufacturer. Its head office is located in Chicago, Illinois. Its two largest plants are located in Wichita, Kansas and Everett, near Seattle. This aircraft manufacturer specializes in the design of civil aircraft, but also in military aircraft, helicopters and in satellites and rockets with its Boeing Defense, Space and Security division. In 2012, it ranks second in world military equipment sales. The company was born on July 15, 1916, thanks to its two fathers William E. Boeing and George Conrad Westervelt and is named "B and W". Shortly afterwards, his name became "Pacific Aero Products" and finally "Boeing Airplane Company". In 1938, Boeing commissioned the 307 Stratoliner; It was the first airplane with pressurized cabin; He was able to fly at a cruising altitude of 20,000 feet, so above most weather disturbances, making him the strongest aircraft in the Boeing fleet. In response to the concentration move in the US defense industry initiated by its competitor Lockheed in 1995, Boeing acquired Rockwell International's space and defense operations in August 1996 for \$3.2 billion. Rockwell was the manufacturer of the seven US space shuttles (Enterprise, Pathfinder, Columbia, Atlantis, Endeavor, Discovery and Challenger). Then, Boeing bought the number two defense equipment behind Lockheed Martin that is McDonnell Douglas, for \$13 billion in August 1997. McDonnell Douglas was the manufacturer of the Delta launchers. In 1999, the Boeing aircraft manufacturer sold 620 aircraft; in 2004, deliveries fell to 285 aircraft. It is now overtaken by its European competitor Airbus in orders since 2002 and in deliveries since 2004 (Source: Le Monde, 13 June 2005). In 2005, in a record market, the company announces 1,005 orders (of which 569 B737, 235 B787 and 154 B777) surpassed again by Airbus of about fifty aircraft. Boeing became the world's first aircraft manufacturer in 2006 with 1,044 orders versus 824 for Airbus. In 2008, Boeing is the world leader in the defense sector. In November 2016, Boeing announced a restructuring of its defense arm with the suppression of 500 positions, the closure of two plants in El Paso and Newington and the displacement of 2,000 employees.

Keywords: Aviation, Boeing, Aeronautical, Aerospace Manufacturer, Boeing Industry, Military Aircraft, Defense Sector

\section{Introduction}

Boeing is an aeronautical and aerospace manufacturer. Its head office is located in Chicago, Illinois. Its two largest plants are located in Wichita, Kansas and Everett, near Seattle. This aircraft manufacturer specializes in the design of civil aircraft, but also in military aircraft, helicopters and in satellites and rockets with its Boeing Defense, Space and Security division (Boeing; Boeing, From Wikipedia). In 2012, it ranks second in world military equipment sales. The company was born on July 15,1916 , thanks to its two fathers William E. Boeing and George Conrad Westervelt and is named "B and W". 
Shortly afterwards, his name became "Pacific Aero Products" and finally "Boeing Airplane Company". In 1938, Boeing commissioned the 307 Stratoliner; It was the first airplane with pressurized cabin; He was able to fly at a cruising altitude of 20,000 feet, so above most weather disturbances, making him the strongest aircraft in the Boeing fleet. In response to the concentration move in the US defense industry initiated by its competitor Lockheed in 1995, Boeing acquired Rockwell International's space and defense operations in August 1996 for $\$ 3.2$ billion. Rockwell was the manufacturer of the seven US space shuttles (Enterprise, Pathfinder, Columbia, Atlantis, Endeavor, Discovery and Challenger). Then, Boeing bought the number two defense equipment behind Lockheed Martin, that is McDonnell Douglas, for $\$ 13$ billion in August 1997. McDonnell Douglas was the manufacturer of the Delta launchers. In 1999, the Boeing aircraft manufacturer sold 620 aircraft; in 2004, deliveries fell to 285 aircraft. It is now overtaken by its European competitor Airbus in orders since 2002 and in deliveries since 2004 (Source: Le Monde, 13 June 2005). In 2005, in a record market, the company announces 1,005 orders (of which 569 B737, 235 B787 and 154 B777) surpassed again by Airbus of about fifty aircraft. Boeing became the world's first aircraft manufacturer in 2006 with 1,044 orders versus 824 for Airbus. In 2008, Boeing is the world leader in the defense sector. In November 2016, Boeing announced a restructuring of its defense arm with the suppression of 500 positions, the closure of two plants in El Paso and Newington and the displacement of 2,000 employees (Petrescu and Petrescu, 2011; 2012; 2013a; 2013b; 2013c).

\section{Boeing History}

In March 1910, William E. Boeing bought the shipyard Heath in Seattle on the river Duwamish, who later became the first factory of the plane. Boeing has been incorporated in Seattle by William Boeing on 15 July 1916, as "Pacific Aero Products Co". Boeing later has been incorporated in Delaware, the registration certificate has been deposited with the secretary of state from Delaware, on 19 July 1934. Boeing, who has studied at the Yale University, has worked initially in the Wood Industry, where has become rich and learned about the wooden structures.

This knowledge proved to be invaluable in the design of the subsequent and assembling of aircraft. The company has remained in Seattle to take advantage of the offer of local spruce wood.

William Boeing has founded the company to a few months after 15 June of the inaugural flight of one of the two seaplanes "B and W" built using George Conrad Westervelt an engineer US titles. Boeing Westervelt and decided to build seaplane $\mathrm{B}$ and $\mathrm{W}$ after he flew into a Curtiss biplane aircraft. Boeing bought a Glenn Martin "Flying Birdcage" a (so-called because of all the typewires which together hold) and has been taught to fly by Glenn Martin himself. Boeing crashed soon the cage and when Martin informed the Boeing spare parts should not become available for months, Boeing realized that could build your own aircraft in that period of time. Him and his friend or the Democratic Convention (CDR). George Conrad Westervelt has agreed to build a better and soon seaplane product B and W. This first Boeing plane has been assembled in a hangar on the shore of the lake located on the banks of the north-east of the Lake Union Seattle. Many of the aircraft early Boeing have been seaplanes.

The company was born on July 15, 1916, thanks to its two fathers William E. Boeing and George Conrad Westervelt and is named "B \& W". Shortly afterwards, his name became "Pacific Aero Products" and finally "Boeing Airplane Company".

On 6 April, 1917, USA declared war on Germany and later in the course of the year in the First World War I. On 9 May 1917, the company became the "Company Boeing Airplane". With the entry in the war in the USA, Boeing knew that US Titles seaplanes necessary for training. So Boeing was sent two new model Cs for Pensacola, Florida, in the case in which those airplanes were flown to the Marina. Marina liked the $\mathrm{C}$ and ordered the 50 May. The company moved its operations in a former installation the shipbuilding greater, known under the name Boeing Plant 1, situated on the lower Duwamish, Washington State.

In 1917, with the entry of the United States, the Navy ordered 50 Model C training aircraft, the first order from Boeing.

At the end of the First World War, in 1918, a surplus of cheap military aircraft used floods on the market, preventing airlines from selling any new aircraft, leading many businesses. Others, including Boeing, began selling other products. Boeing built cabinets, stands and furniture along with flatbottomed boats called Sea Sleds.

In 1919 Boeing B-1, the flight boat made its first flight. He hosted a pilot and two passengers and several emails. Within eight years, he made international flights by plane from Seattle to Victoria, British Columbia. On May 24, 1920, Boeing 8 made his first flight. It was the first plane flying over Mount Rainier.

In 1923, Boeing competed against Curtiss to develop a US Air Force fighter. Although Curtiss finished his project and received the contract, Boeing continued to develop his PW-9 fighter. The plane, along with the Boeing P-12/F4B fighter, made Boeing a major aircraft manufacturer over the next decade.

In 1925, Boeing built his Model 40 aircraft for the US government, which he used for air routes. In 1927, an improved version of this $40 \mathrm{~A}$ aircraft was built, which 
won the US email contract to deliver mail between San Francisco and Chicago. The $40 \mathrm{~A}$ also had a passenger cabin that housed two. In 1923, Boeing manufactured a 40A postal aircraft and in 1927 he won a contract for San Francisco-Chicago Air Service.

Boeing then created "Boeing Air Transport" to handle its air transport activities. In the first year, nearly 2,000 passengers were transported and specially designed passenger planes built and launched in the 1980s. In the years that followed, Boeing began to acquire a number of aircraft, engine and airline companies and in 1929 Boeing changed its name to United Aircraft and Transport Corporation.

In 1934, Boeing became a major airline, motor, mail, airport and airline. But according to an ant it rust law that forbids manufacturers to operate airlines, its creators sell their possessions and "United Aircraft and Transport" is divided into three entities:

- United Airlines responsible for air transport

- United Aircraft, responsible for production in the east of the country

- Boeing Airplane Company responsible for production in the west of the country

- The Boeing Plant 2 production site is operational between 1936 and 1970

Soon after, an agreement was signed with Pan American World Airways to develop and produce a commercial seaplane capable of transporting passengers on transatlantic routes. Boeing 314 Clipper made his first flight in June 1938. It was the largest civilian aircraft of his time capable of transporting daily flights and 40 passengers on night flights. A year later, the first US commercial line in the United Kingdom was inaugurated. There were other air routes that operated Boeing 314 (Boeing).

In 1938, Boeing ordered Stratoliner 307; It was the first airplane with pressure booth; He managed to fly at an altitude of 20,000 feet, so most of the time, making him the most powerful aircraft in the Boeing fleet.

During the Second World War, Boeing built a large number of bombers B-17 and B-29. Many of the workers were women whose husbands went to war (Boeing, From Wikipedia).

Boeing has developed military planes such as B-47 Stratojet bombers and B-52 Stratofortress in the late 1940s and 1950s. In the early 1950's, Boeing used funds from the company to develop a 367-80 number, Led to KC-135 Stratotanker and Boeing 707. Some of these were built at the Boeing facilities in Wichita, Kansas, which existed between 1931 and 2014.

In the mid-1950's, technology advances significantly, which has allowed Boeing to develop and produce new products. One of the first was the short-range missile used to intercept the enemy plane. At that time, the cold war became a fact of life and Boeing used a short-range technology to develop and build an intercontinental missile.

In 1958, Boeing began delivering its first commercial airliner 707 to the United States in response to British De Havilland Comet, France, South Caravelle and Tupolev Tu-104 Soviet, which were the first generation of commercial jet aircraft in the world. With 707, a fourengine plane and 156 passengers, the US. He has become a leader in branding. A few years later, Boeing added a second version of this aircraft, the Boeing 720, which was slightly faster and had a shorter range.

Boeing was an important manufacturer of small turbine engines in the 1950s and 1960s. The engines were one of the company's major efforts to expand its product base beyond military aircraft after the Second World War. The development of the gas turbine engine began in 1943 and the Boeing gas turbines were designated 502, 520, 540, 551 and 553. Boeing built 2,461 engines before production ceased in April 1968. Many engine applications with a Boeing gas turbine were the first, including the first helicopter and the turbine boat.

Mufti Vertol Corporation was acquired by Boeing in 1960 and was reorganized as a division of Boeing Vertol. The Chinook rotor-CH-47 Chinook, produced by Vertol, took its first flight in 1961. This high helicopter lifter remains a horse-powered vehicle to date. In 1964, Vertol began production of Sea Knight CH-46.

In December 1960, Boeing announced the 727 jetliner, which entered commercial service about three years later. Various transport options for passengers, wagons and cabriolets have been developed for the 727 model. 727 was the first commercial jet to reach 1000 sales.

Boeing won a contract in 1961 to produce the S-IC phase of the Saturn V rocket, manufactured at Michoud's installation facility in New Orleans, Louisiana.

In 1966, Boeing President William M. Allen asked Malcolm T. Stamper to launch the new 747 flight plan, which was the company's future. This was a monumental challenge in engineering and management and included the construction of the largest factory in the world to build 747 from Everett, Washington, a factory that has the size of 40 football fields.

In 1967, Boeing introduced another short- and medium-range aircraft, the 737 engine. Since then, it has become the best-selling commercial aircraft in the history of aviation. Several versions have been developed, mainly to enhance the capacity and range of seats. Product 737 remains in production until April 2017.

The launch of ceremonies for the first 747-100 took place in 1968 at the new massive factory in Everett, about an hour's drive from Seattle's Boeing home. The 
aircraft made its first flight a year later. The first commercial flight took place in the 1970s. The 747 has an intercontinental range and a higher seating capacity than Boeing's earlier aircraft.

Boeing also developed hydrophones in the 1960s. The USS Peak Screw (1-PCH) was a submarine experimental hunter. The USC Tucumcari Keyboard (PGH-2) was more successful. Only one was built but saw service in Vietnam and Europe before the failure of 1972. It is with a jet of water and the completely sunken flight sheet was the example for later on the patrol class of the Pegasus submarines and ferries 929 Jetfoil In the 1980s. Tucumcari and boats were subsequently produced in Renton. While the merchant marina withdrew from submarine wings at work in late 1980, Jetfoils Boeing is still in service in Asia.

In the early 1970s, Boeing suffered a decline in the simultaneous presence of the Vietnam War, the slowdown of the Apollo Space Program as a close project, the recession of 1969-1970 and the \$2 billion company due to the debt that built the New 747 Aircraft Boeing has already received orders for more than a year. His bet for the future, 747, was delayed in three-month production due to problems with the Pratt and Whitney engines. Another problem was that in 1971, the American Congress decided to stop the financing of supersonic development 2707, Boeing's response to the British-French Concorde, forcing the company to interrupt the project.

The Airplane marketing group, by far the largest Boeing unit, moved from 8.3700 employees in 1968 to 20,750 in 1971. Each Boeing employee hired at least one other job and unemployment increased by $14 \%$, the most Sea in the United States. Serious employment rates rose to $16 \%$, from $1 \%$ in 1967 . Dealers in $U$ have left the transport because many people have moved. A billboard appeared in the vicinity of the airport.

In January 1970, the first 747, a four-engine longrange aircraft, flew its first commercial flight to Pan American World Airways. The 747 has changed the aerospace industry, offering a much higher capacity than any other production aircraft. The company delivered more than 1500 Boeing 747 models. The 747 product has undergone continuous improvement to keep it technologically up-to-date. Larger versions have also been developed by stretching the upper deck. The latest version of the 747, the 747-8 is in production since 2016.

Boeing launched three 929-100 hydrophones purchased in 1975 for service in the Hawaiian Islands. When the service ended in 1979, the three hydrophones were acquired by Far East Hydrofoil for service between Hong Kong and Macao.
In the 1970s, Boeing developed the US Light Rail Rail Vehicle model used in San Francisco, Boston and Morgantown, West Virginia.

In 1983, the economic situation began to improve. Boeing assembled a 737-passenger aircraft. In the coming years, commercial airplanes and their army became the basic equipment of airlines and air forces. As passenger traffic has increased competition, it has been more difficult, especially from Airbus, that a new European has arrived in the manufacture of passenger aircraft. Boeing had to provide new aircraft and developed a single 757 corridor, the largest 767 corridor and upgraded versions of 737. An important project of these years was the space shuttle, to which the state contributed with experience in the space rocket gained in the era Apollo. Boeing also participated in the other space program programs and was the first participant at the International Space Station.

Over the decade, several military projects have entered production, including the Boeing stealth B-2 bomber. As part of a Northrop-led team, Boeing built the exterior of the B-2 bomber, cage center, landing system, fuel system and weapon delivery system. At its peak in 1991, B-2 was the largest military program at Boeing, employing about 10,000 people. In the same year, the Aviation Authority of the United States National Association awarded the B-2 design trophy for America's largest aerospace industry achievement. The first B-2 laminated from the final assembly in Palmdale, California in November 1988 and flew for the first time on July 17, 1989.

The air defense system against airplanes and a new generation of short-range missiles have also entered production. In these years, Boeing has been very active in modernizing existing military equipment and developing new ones. Boeing has also contributed to the development of experimental wind turbines- 2 for NASA and the US Department of Energy and a-5B for Hawaii.

Boeing was one of the seven companies to bid for Advanced Tactical Fighter. Boeing has agreed with General Dynamics and Lockheed, so all three companies will participate in the development if one of the three company models has been selected. Finally, Lockheed's design was selected and developed in the F-22 Raptor.

\section{F-22 Raptor}

Lockheed Martin F-22 Raptor is a one-sided, two sided format for the United States Air Force (USAF). The result of the Advanced Fighter Tactical USAF, the aircraft was primarily designed as a superior combat aircraft but also has a ground attack, 
electronic warfare and signal intelligence capabilities. The main contractor, Lockheed Martin, built the bulk of F-22 weapons systems and completed the final assembly, while Boeing supplied wing systems, fuselage, avionics integration and training Fig. 1.

The aircraft was designated in a F-22 and F/A-22 before it was officially introduced by the F-22A service in December 2005. After prolonged development and despite operational problems, the USAF believes F-22 Is essential for his tactical Air, saying the aircraft is unmatched by any known or planned fighter, combining stealth, aerodynamic performance and Raptor's awareness of the company's unprecedented capability.

The high cost of the aircraft, the lack of clear air from delays in Russian and Chinese combat programs, the ban on exports and the development of a more versatile F-35 led to the end of the F-22 production. A record acquisition of 187 operational productions was set up in 2009 and the last F-22 was delivered in 2010 in the USAF.

Main contractor Lockheed Martin manufactured the majority of the aircraft body and completed the final assembly at the Dobbins Air Reserve in Marietta, Georgia; A Boeing Defense Channel partner program, Space and Security has provided components for additional body aircraft as well as system integration and avionics training. F-22 production has been divided into several subcontractors with more than 46 members to increase Congress support, although this can be divided by production, contributed to increased costs and delays.

Many capacities have been postponed to improve post-service, reducing the initial cost but increasing the total cost of the program.

The production supported over 1,000 subcontractors and suppliers and up to 95,000 jobs.

The F-22 had many design changes from the YF-22. The angle of the posterior rim of the mature dropped from 48 to $42^{\circ}$, while the vertical stabilizers were moved back and down in the area by $20 \%$. To improve the visibility of the pilot, the canopy was moved before 7 inches $(18 \mathrm{~cm})$ and the engine moved back four inches $(36 \mathrm{~cm})$.

The shape of the wings and stabilization edges has been improved to improve aerodynamic, strength and stealth characteristics. Weight gain during easy development has reduced aerodynamic performance and performance.

The F-22 Raptor is a fifth-generation fighter who is considered the fourth generation of the USF stealth plane technology. It is the first operational aircraft that combines super cruise, super maneuverability, stealth and fusion of sensors into a single weapon platform.

The raptor cut off the wings of the delta with a broom back, four spreading surfaces and a retractable tricycle landing system. Flight control surfaces include top flaps, flaps, eilerons, riders on vertical sliding stabilizers and horizontal queues in motion; these surfaces also serve as speed brakes (Lockheed Martin F-22 Raptor, from Wikipedia).

In response to the concentration move in the US defense industry initiated by its competitor Lockheed in 1995, Boeing acquired Rockwell International's space and defense operations in August 1996 for \$3.2 billion.

Rockwell was the manufacturer of the seven US space shuttles (Enterprise, Pathfinder, Columbia, Atlantis, Endeavor, Discovery and Challenger).

Then, Boeing bought the number two defense equipment behind Lockheed Martin that is McDonnell Douglas, for $\$ 13$ billion in August 1997. McDonnell Douglas was the manufacturer of the Delta launchers.

In 1999, the Boeing aircraft manufacturer sold 620 aircraft; in 2004, deliveries fell to 285 aircraft. It is now overtaken by its European competitor Airbus in orders since 2002 and in deliveries since 2004 (Source: Le Monde, 13 June 2005). In 2005, in a record market, the company announces 1,005 orders (of which 569 B737, 235 B787 and 154 B777) surpassed again by Airbus of about fifty aircraft.

End of 2005: The order book includes 1809 deliverables for the next 7 years. Deliveries 2005: 290 planes-320 scheduled not delivered due to a one month strike that blocked the major US production and assembly plants in December. These thirty aircraft were pushed back on 2006 and 2007 in addition to the already estimated deliveries:

- $\quad$ Planned deliveries 2006: 395 aircraft

- Planned deliveries 2007: 445 aircraft

Sales figures: 2005 sales: $\$ 55$ billion ( $€ 45.8$ billion). 2006 estimated sales: $\$ 60$ billion ( $€ 50$ billion). Estimated turnover in 2007: $\$ 64$ billion ( $€ 53.3$ billion). Net profit for 2005: $\$ 2.60$ billion ( $€ 2.16$ billion).

The new B 787 was a commercial success, it claims at the end of 2005,291 firm orders and 88 purchasing intentions of 27 companies. Its production is expected to start in mid-2007 for a planned entry into service in 2008. If its success is confirmed, some analysts predict supply shortages of certain suppliers and production rate problems, as Boeing already experienced in 1997 (Boeing, From Wikipedia).

In 2005, Boeing employed more than 245,000 employees in the United States and their salaries ranged around $\$ 45,000 /$ Year to a maximum of $\$ 67 / \mathrm{h}$ (\$127,000/year).

Boeing became the world's first aircraft manufacturer in 2006 with 1,044 orders versus 824 for Airbus.

In 2008, Boeing is the world leader in the defense sector. 


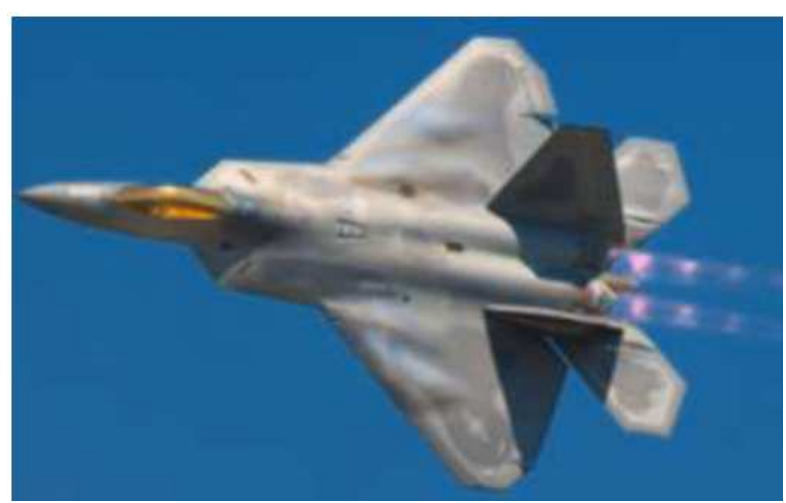

Fig. 1. A pilot peers up from his F-22 Raptor while inflight, showing the top view of the aircraft Source: https://en.wikipedia.org/wiki/Lockheed_Martin_F22_Raptor\#/media/File:Lockheed_Martin_F22A_Raptor_JSOH.jpg

Boeing delivered 481 commercial aircraft in 2009, a $28 \%$ increase over 2008. The Boeing 737 is still popular with airlines, with 372 deliveries, 88 deliveries for the Boeing 777, 13 deliveries for the Boeing 767 and 8 deliveries for the Boeing 747. Boeing's backlog is now 3,375 Including 2,076 Boeing 737 aircraft.

In March 2011, Boeing entered into an agreement with two Chinese air carriers for a total of 43 aircraft totaling approximately US $\$ 10$ billion. Air China plans to buy 5 Boeing 747-8 aircraft. If the agreement is approved by the Chinese government, delivery of the aircraft of this new model of 747 is planned between 2014 and 2015 (Boeing, From Wikipedia).

\section{Dreamliner Aircraft}

The Boeing 787, also known by its nickname Dreamliner, is a long-haul aircraft. Officially launched on April 26, 2004 for commissioning in May 2008, it makes its first flight on December 15, 2009 and is certified on August 26, 2011. The first delivery of the Boeing 787-8 Dreamliner took place on September 26, 2011 at all Nippon Airways Fig. 2.

This aircraft carries between 210 and 330 passengers according to the versions and configurations and is more fuel efficient: According to Boeing's initial specifications, a 20\% lower consumption than an Airbus A330 or a Boeing 777.

The first flight was scheduled to take place at the end of July 2007 , for an entry into service initially scheduled for May 2008. Two months after its public presentation on 8 July 2007 (written 7/8/7 in American format), a first delay of 3 months was announced due to a shortage of fixations (July 8, 2007 the device presented was built with temporary fixations that had to be removed) and software development issues.

A month later (October 2007), a second delay of three months was announced, for the same reasons, to which were added difficulties in the logistic organization of the manufacture. In the same month the program manager was replaced. In January 2008, third delay of 3 months, with the first deliveries to the launch company All Nippon Airways postponed in 2009. In April 2008, following problems with the central box (wing junction part with the fuselage), a fourth delay is announced, postponing the forecast of the first flight in the fourth quarter of 2008 and delaying the first delivery in the third quarter of 2009.

Boeing announced the release of version 3 (787-3 see table below), which was only ordered by Japanese airlines (ANA and JAL). In early November 2008, a fifth deadline was announced. If the primary reason given is the strike of September/October 2008, the discovery of a defect on $3 \%$ of the fixings of the devices or sections already completed is the cause of a further delay. On December 11, 2008, Boeing announced that the first flight was postponed to the second quarter of 2009 and that it was commissioned in the first quarter of 2010 without further details.

On June 15, 2009, during the Paris Air Show, Boeing announced that the 787 would fly on its first flight within two weeks. However, on June 23, 2009, a statement said that due to the need to reinforce part of the structure of the aircraft, the first flight was delayed again, a new schedule not to be communicated until "several weeks".

This postponement of the first test flight was due to the discovery, during the static tests on the wing floor in May, that the composite stiffeners of the extrados were delaminated due to the compressions created by the flexing of the wings. The problem was solved with the installation of titanium fittings at the ends of the stiffeners on the fuselage side and skin stiffeners in the wing.

On 5 July 2009, there were rumors of an additional 18 months, bringing the total delay of the project to almost 4 years. It would be a question of opening a new assembly line (on the Vought Aircraft Industries site in Charleston, South Carolina).

In mid-August 2009, the specialist press reported a letter from Boeing to Alenia Aeronautica, the Italian partner responsible for the central part of the fuselage, asking it to temporarily freeze production because of "wrinkles" in the structure of these Fuselage elements.

On August 27, 2009, the American aircraft manufacturer declared that it was engaging Boeing 787 at All Nippon Airways (ANA), the launch company, in the last quarter of 2010 and not in the first quarter (More initiation, ANA about its first aircraft in May 2008). The program is therefore two and a half years behind schedule. The date of the first flight was repeatedly postponed.

On October 28, 2009, Boeing announced that it is building a second assembly line for the Boeing 787 in North Charleston, South Carolina. 


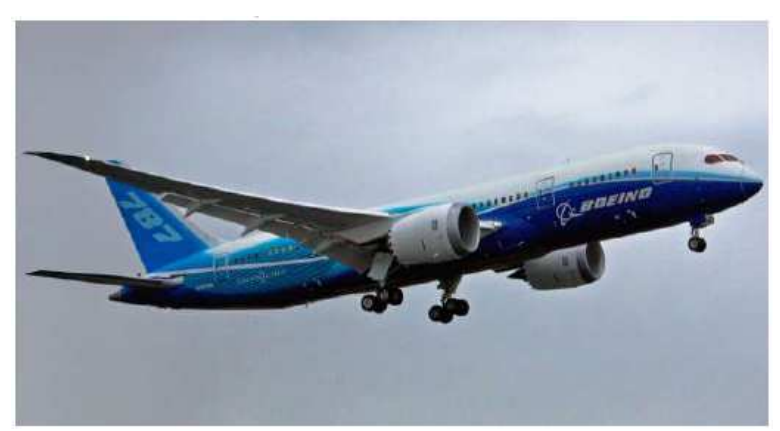

Fig. 2. The Boeing 787 Dreamliner on its first flight Source: https://en.wikipedia.org/wiki/Boeing\#/media/File:Boei ng_7 7_first_flight.jpg

Hong Kong Airlines was interested in purchasing 38 aircraft, including 6 cargo models and 30 Boeing Dreamliner aircraft.

In November 2011, Boeing signed an order to produce "50 long distances 777 for 18 million USD". A few days later he obtained another contract from Lion Air, which will "acquire 230 Boeing 737 for nearly $\$ 22$ billion, of which 201,737 MAX."

In 2014, Boeing achieved the best commercial performance in its history with 1,432 net orders and delivery of 723 civilian aircraft.

In September 2016, Boeing signed an agreement with Morocco to create an "industrial ecosystem" in the kingdom (Boeing, From Wikipedia).

In November 2016, Boeing announced a restructuring of his defense arm by suppressing 500 posts, shutting down two factories in El Paso and Newington and moving 2,000 employees. After $8 \%$ of the aerospace industry in 2016, the Boeing Engineering and Engineering Commission announced in early March 2017 that 1,880 members in the Seattle region accepted voluntary departure (Boeing, From Wikipedia).

As a result of the Second World War, the global aerospace industry was dominated by the United States. Douglas, Boeing and Lockheed have benefited from major US war efforts between 1939 and 1945 and have built a large number of four-pistol military guns whose commercial civil versions (DC-6, Boeing 377, Constellation etc.), Boeing 707, Boeing 720) Airline dominates. In Europe, the aviation industry infrastructure was partially destroyed during the war, but the production resumed rapidly and the first equipped with caravans (Caravelle South-Aviation, Hawker-Siddeley Trident, Vickers VC10, BAC 1-11 from British Aircraft Corporation, etc). It appeared in the 1950s. They were not as successful as their competitors, the Americans sold much less and failed to penetrate the American market.

In the 1960s, mass air transport was booming and an FAA study anticipated a tripling of traffic between 1965 and 1971 for a market of 1,610 aircraft. At the 1965
Paris Exhibition, the main European airlines held informal talks on the short and medium term transport needs that were needed to respond to traffic growth. American manufacturers are involved in the construction of high-capacity aircraft (Lockheed L-1011, Boeing 747, etc.), while, in order to avoid frontal competition, Europeans are interested in a different market. Adapt to the short but dense bands found in Europe and look to develop the idea of "aircraft".

In June 2003, Lockheed Martin sued Boeing, arguing that the company resorted to industrial espionage in 1998 to win the Vehicle Launch Vehicle (EELV). Lockheed Martin argued that former employee Kenneth Branch, who went to work for McDonnell Douglas and Boeing, handed over to new employers nearly 30,000 pages of property documents. Lockheed Martin argued that these documents allowed Boeing to win 19 of the 28 launched satellite launches.

In July 2003, Boeing was penalized, while the Pentagon took seven releases from the company and gave it to Lockheed Martin. In addition, the company was banned from bidding for 20-month missile contracts that expired in March 2005. At the beginning of September 2005, Boeing announced that it is negotiating an agreement with the US Department of Justice to pay 500 million Dollars to cover the Darleen Druyun Scandal.

In the year 2010, Boeing company has completed its acquisition of Argon ST Inc. Based in Fairfax, Virginia, Argon ST develops C4ISR systems (Command, Control, Communications, Computers, Intelligence, Surveillance, Reconnaissance) and combat systems. On 2010, 30 June, Boeing has announced its intention to acquire Argon ST as part of the company's strategy to expand its capabilities to address C4ISR, cybernetic and information markets.

On November 17, 2011, it was reported that Lion Air committed itself to command 201 Boeing 737 MAX and 29 737-900 ER aircraft. This order, when finalized, is worth $\$ 21.7$ billion at list prices. This is higher than any of Boeing's previous sales of commercial aircraft. The agreement includes options for 150 other aircraft. On January 5, 2012, Boeing announced its intention to close Wichita, Kansas, with 2160 workers before 2014, more than 80 years from its inception. Boeing hired 40,000 people there.

Boeing announced on May 13, 2013 that it will cut to 1,500 IT jobs in Seattle, Washington over the next three years, combined with layoffs, wear and relocation. Most of these will be relocated (about 600 jobs each) to St. Louis, Missouri and North Charleston, South Carolina.

\section{Some Models}

In Fig. 3a-3x one can see some models; a-o source: https://en.wikipedia.org/wiki/Boeing. 

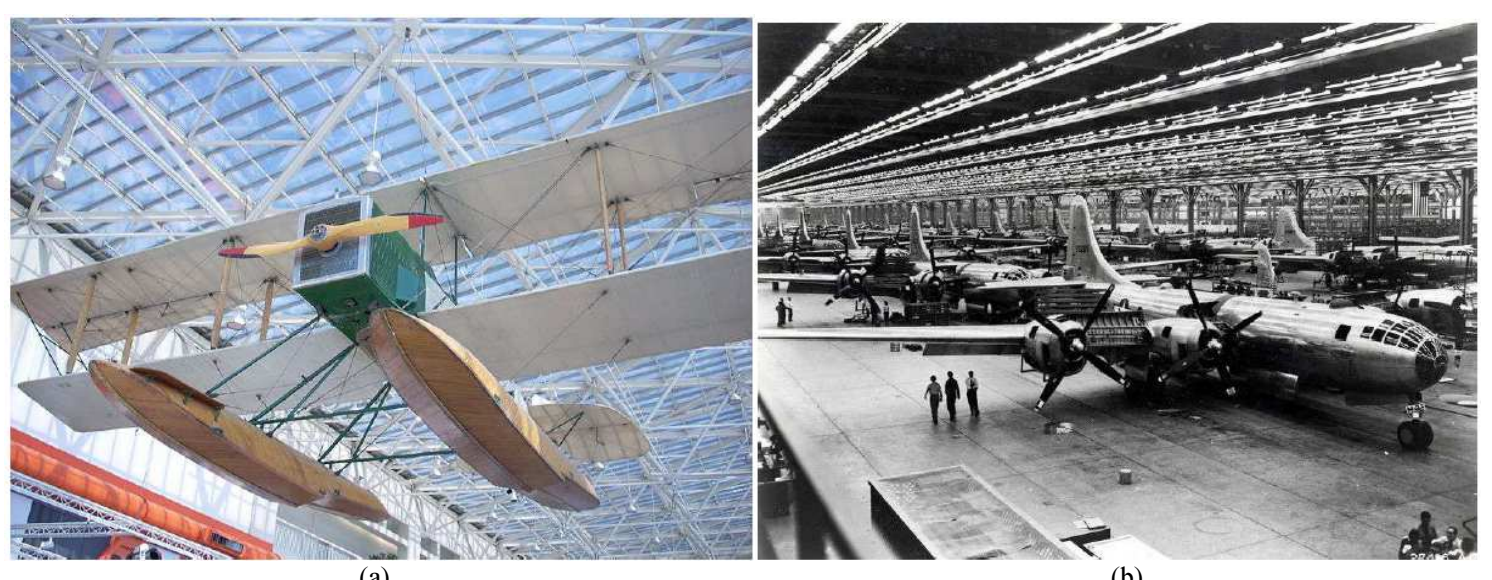

(a)

(b)

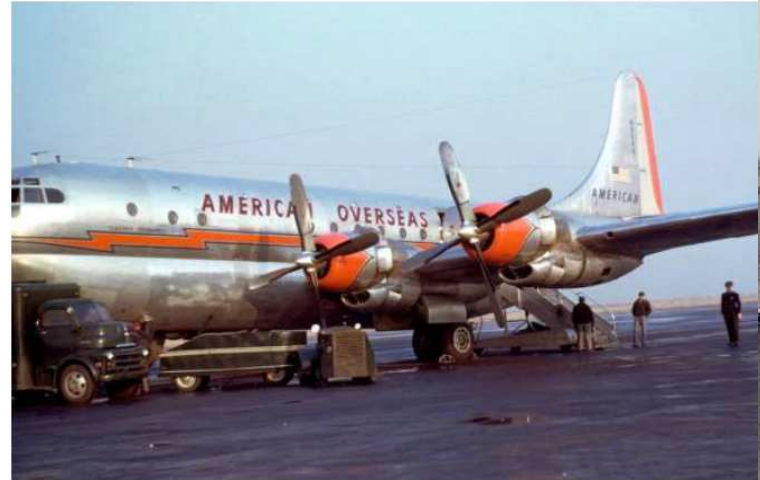

(c)

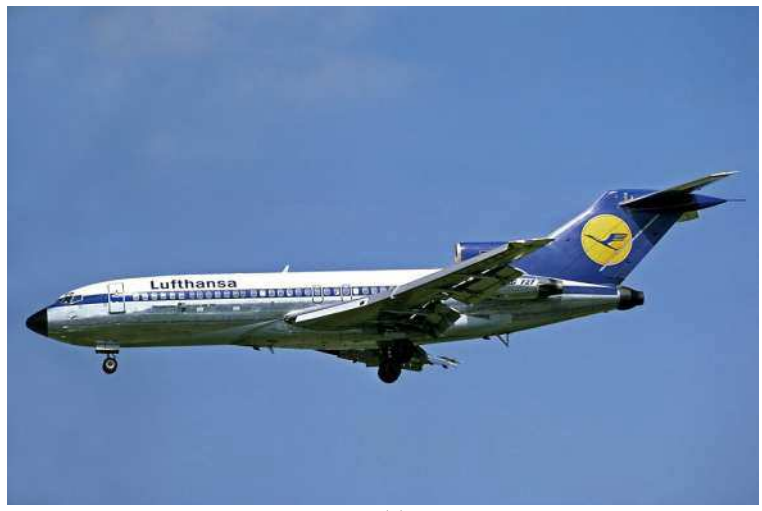

(e)

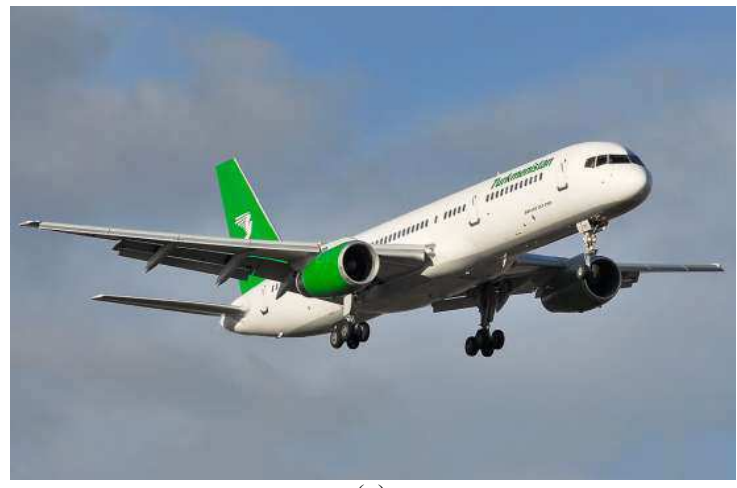

(g)

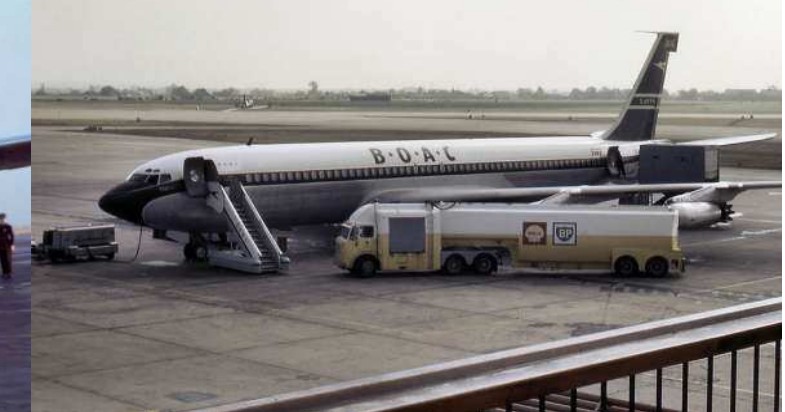

(d)

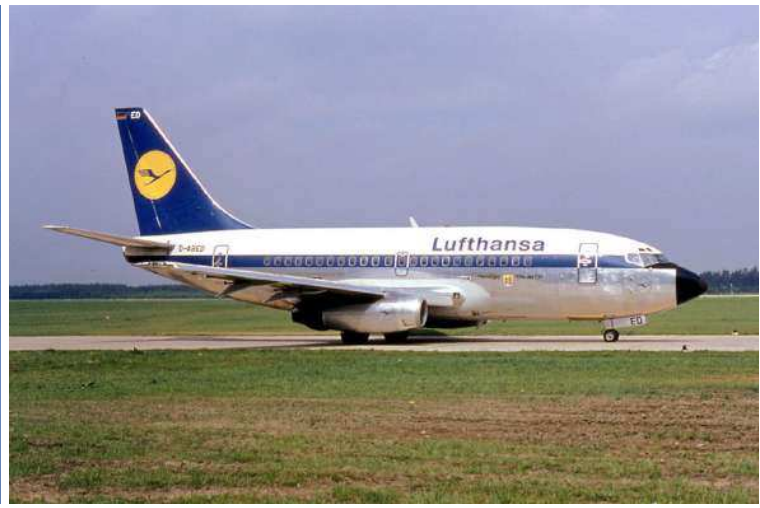

(f)

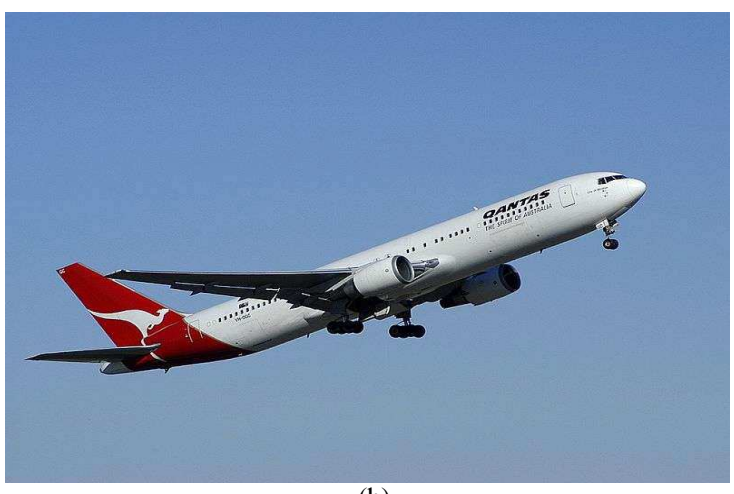

(h) 
Relly Victoria Virgil Petrescu et al. / Journal of Aircraft and Spacecraft Technology 2017, 1 (3): 149.161 DOI: 10.3844/jastsp.2017.149.161

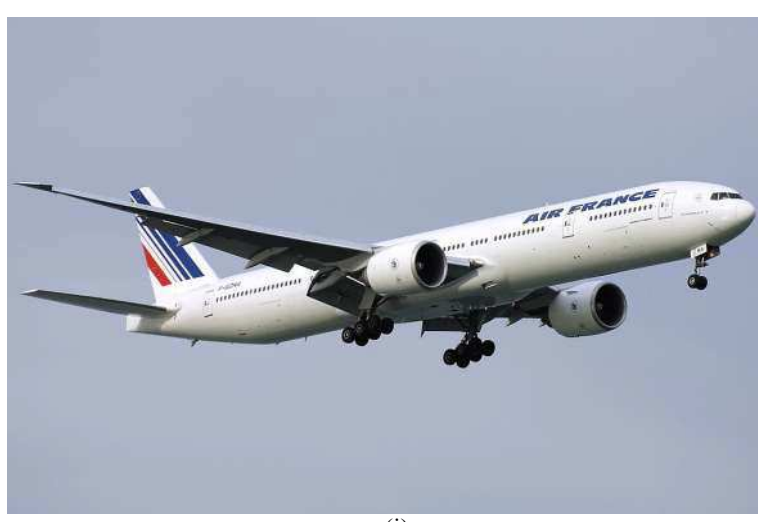

(i)

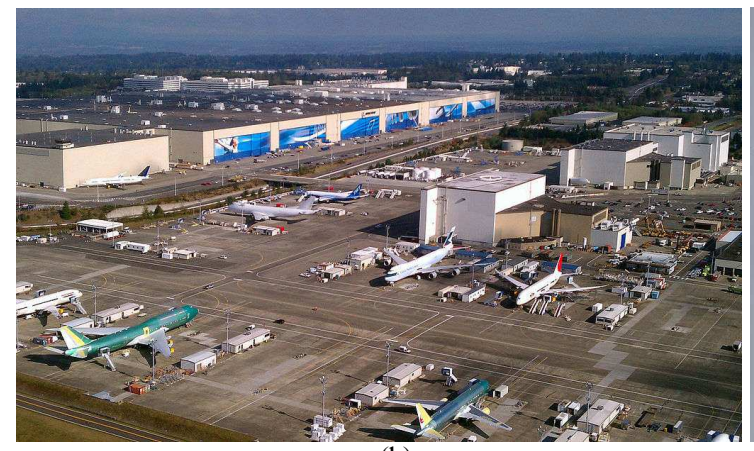

(k)

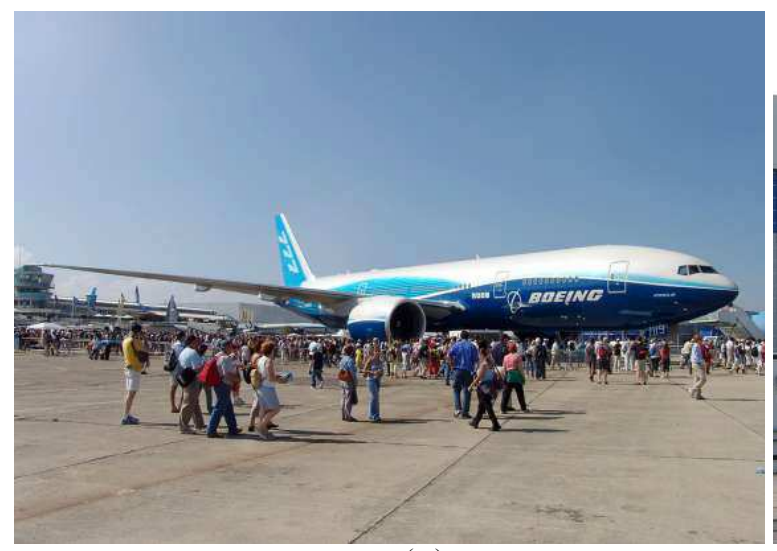

(m)

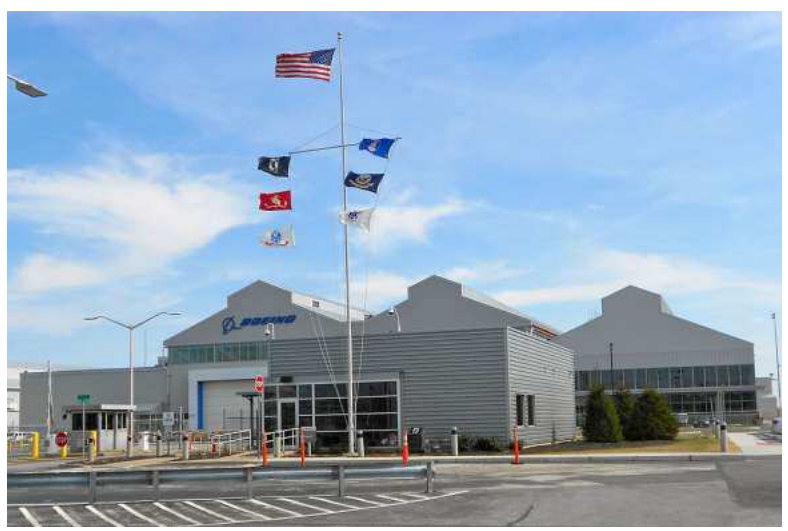

(o)

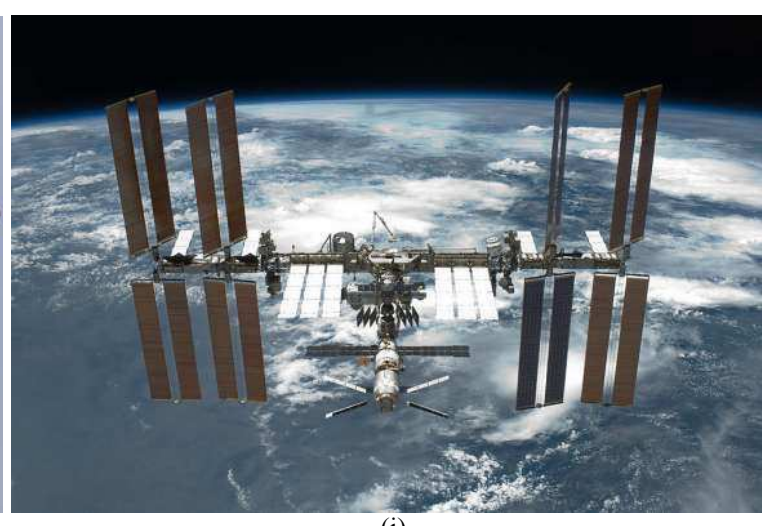

(j)

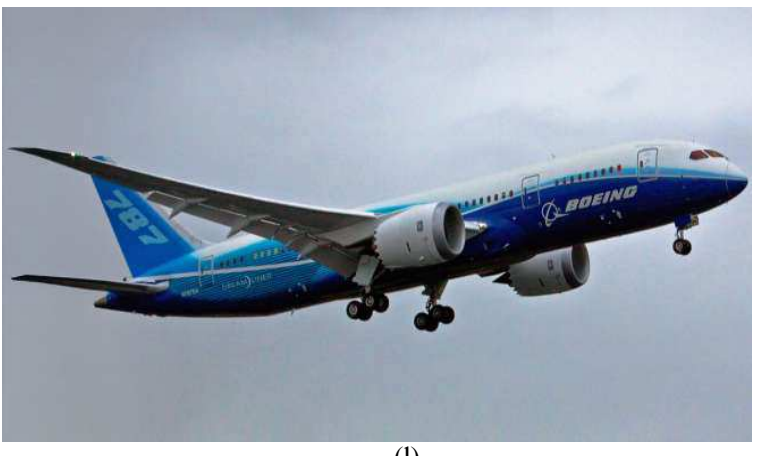

(1)

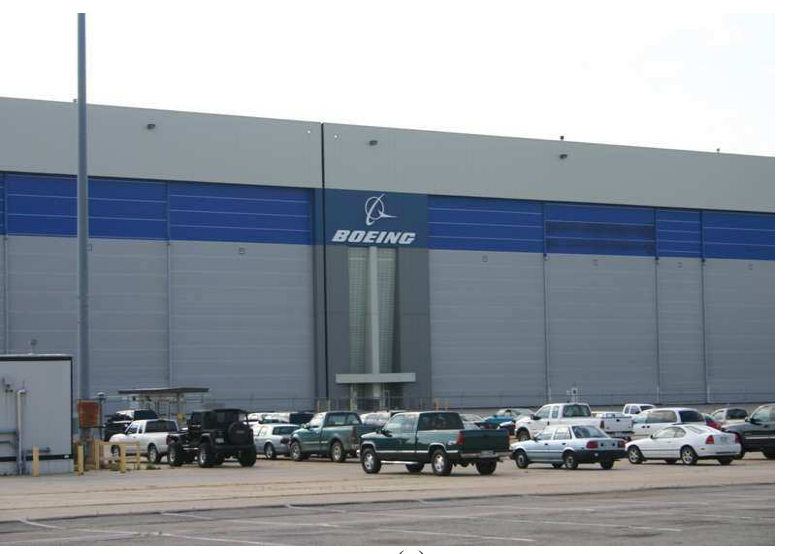

(n)

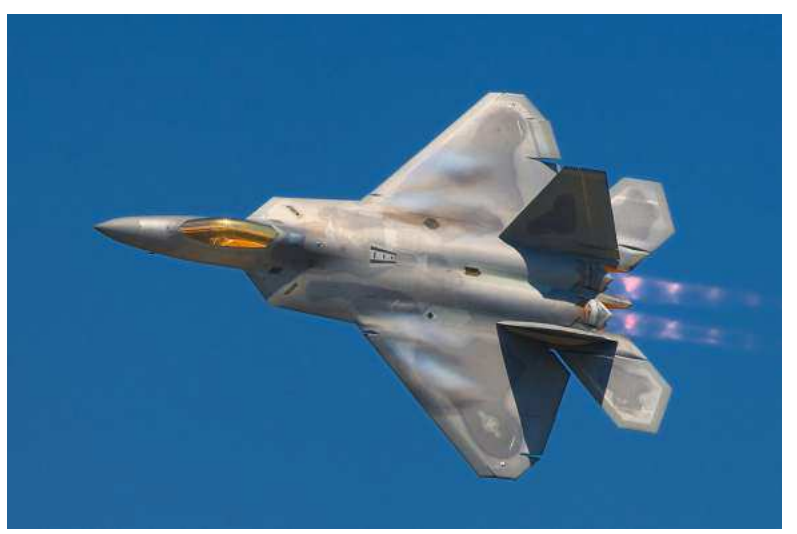

(p) 


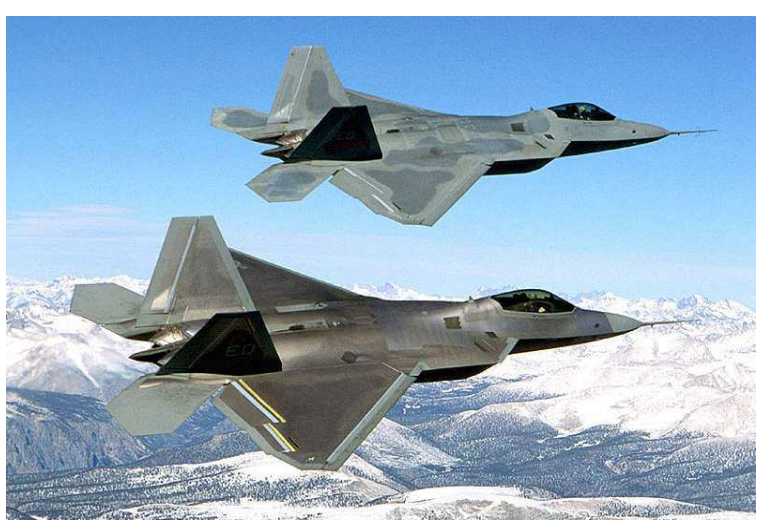

(q)

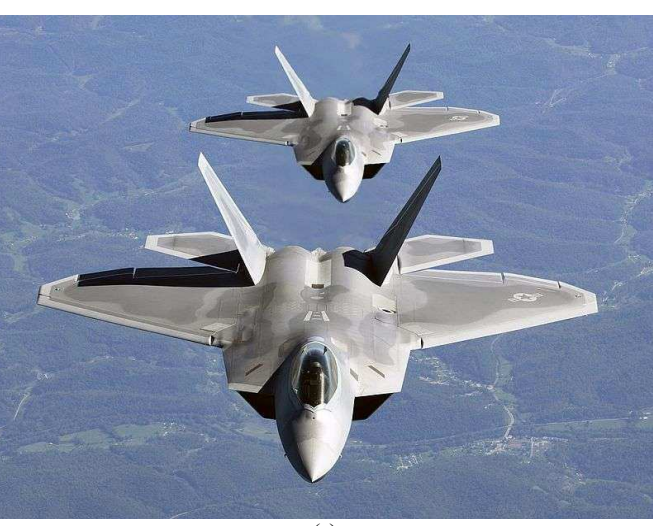

(r)

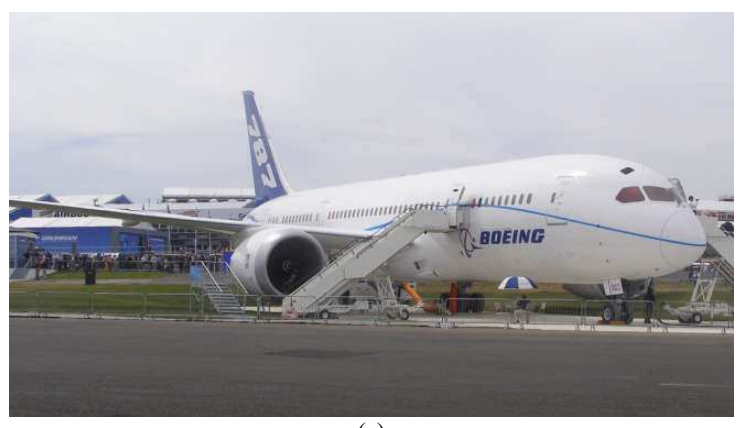

(s)

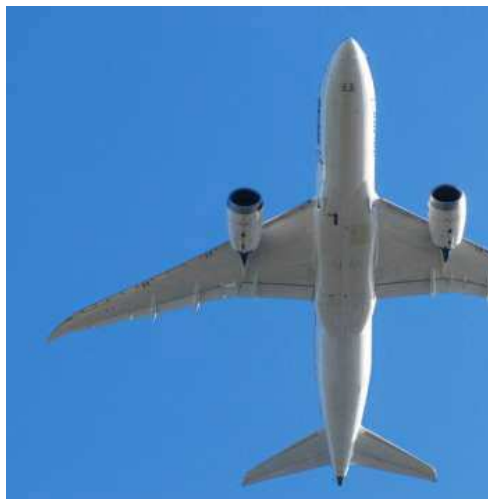

(u)

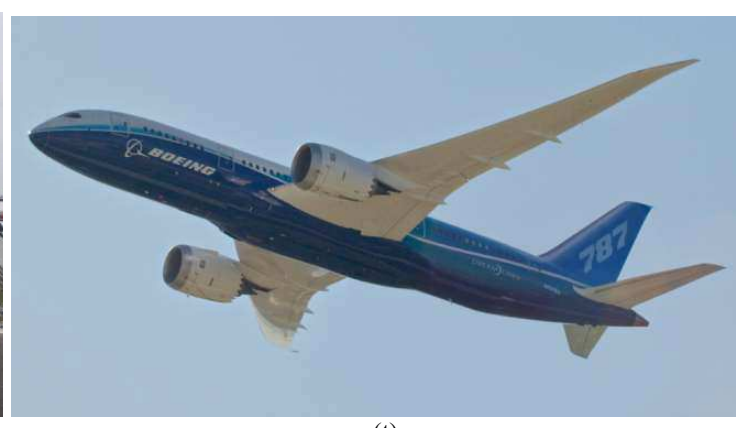

(t)

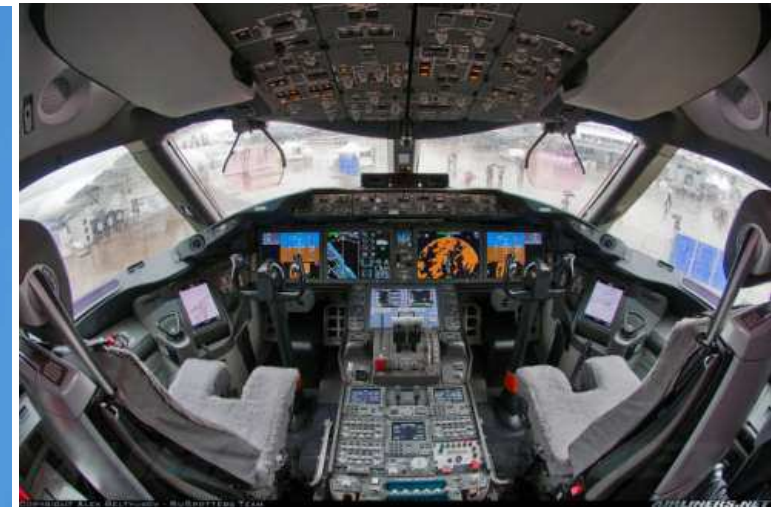

(v)
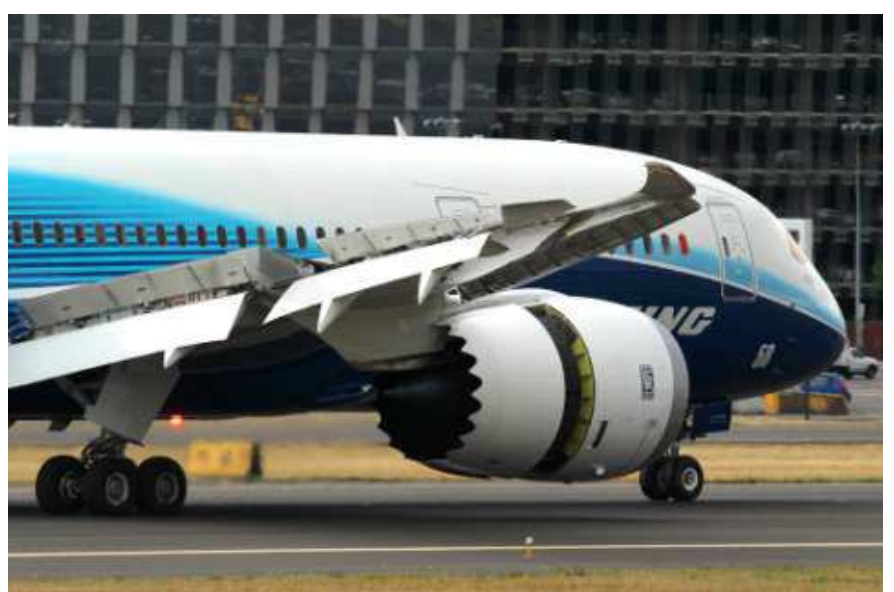

(w) 


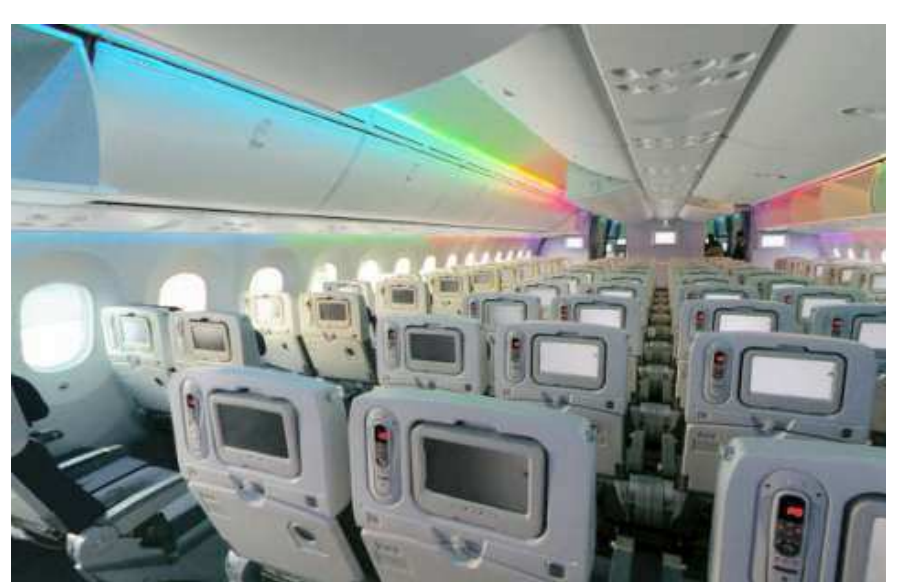

$(\mathrm{x})$

Fig. 3. (a) Replica of Boeing's first plane, the Boeing Model 1, at the Museum of Flight; (b) Boeing B-29 assembly line in Wichita, Kansas, 1944; (c) Boeing 377 Stratocruiser; (d) The Boeing 707 in British Overseas Airways Corporation (BOAC) livery, 1964; (e) Lufthansa Boeing 727; (f) A Boeing 737, the best-selling aircraft; (g) The narrow body Boeing 757 replaced the 727. This example is in Turkmenistan Airlines livery; (h) The Boeing 767 replaced the Boeing 707. This example is in Qantas livery; (i) Air France 777-300ER; (j) International Space Station; (k) Boeing Everett Factory in 2011; (l) The Boeing 787 Dreamliner on its first flight; (m) The record-breaking 777-200LR Worldliner, presented at the Paris Air Show 2005; (n) Boeing's Wichita plant in 2010. Boeing ended its presence in Kansas in 2012-13; (o) Boeing plant in Ridley Park, Pennsylvania; (p) Lockheed Martin F-22 Raptor. Source: https://en.wikipedia.org/wiki/Lockheed_Martin_F22_Raptor\#/media/File:Lockheed_Martin_F-22A_Raptor_JSOH.jpg; (q) Two F-22s during flight testing, the upper one being the first EMD F-22, Raptor 4001. Source: https://en.wikipedia.org/wiki/Lockheed_Martin_F-22_Raptor\#/media/File:Two_F22_Raptor_in_flying.jpg (r); Two F-22As in close trail formation. Source: https://en.wikipedia.org/wiki/Lockheed_Martin_F22_Raptor\#/media/File:Two_F-22A_Raptor_in_column_flight_-_(Noise_reduced).jpg; (s) After electrical system and software changes, the 787 resumed company flight testing on December 23, 2010 (Petrescu and Petrescu, 2012); (t) After electrical system and software changes, the 787 resumed company flight testing on December 23, 2010 (Petrescu and Petrescu, 2012); (u) External features include raked wingtips and engine nacelles with noise-reducing serrated edges. The longest-range 787 variant can fly 8,000 to 8,500 nautical miles (15,000 to $15,700 \mathrm{~km})$, enough to cover the Los Angeles to Bangkok or New York City to Hong Kong routes. It has a cruising airspeed of Mach $0.85(561 \mathrm{mph}, 903 \mathrm{~km} / \mathrm{h}$ at typical cruise altitudes). (Petrescu and Petrescu, 2012); (v) The 787 flight deck features LCD multi-function displays, all of which will use an industry standard GUI widget toolkit (Cockpit Display System Interfaces to User Systems/ARINC 661). The 787 flight deck includes two Head-Up Displays (HUDs) as a standard feature. Like other Boeing airliners, the 787 will use a yoke instead of a side-stick (Petrescu and Petrescu, 2012); (w) The two different engine models compatible with the 787 use a standard electrical interface to allow an aircraft to be fitted with either Rolls-Royce Trent 1000 or General Electric GEnx engines. This aims to save time and cost when changing engine types; while previous aircraft can have engines changed to those of a different manufacturer, the high cost and time required makes it rare. In 2006, Boeing addressed reports of an extended change period by stating that the 787 engine swap was intended to take $24 \mathrm{~h}$; engine interchangeability, it is reported, makes the 787 a more flexible asset to airlines, allowing them to change easily from one manufacturer's engine to the other if required (Petrescu and Petrescu, 2012); (x) The 787-8 is designed to seat 234 passengers in a three-class setup, 240 in two-class domestic configuration and 296 passengers in a high-density economy arrangement. Seat rows can be arranged in four to six abreast in first or business (e.g., 1-2-1, 2-2-2), with eight or nine abreast in economy (e.g., 3-2-3, 2-4-2, 3-3-3). Typical seat room ranges from 46 to 61 in $(120$ to $150 \mathrm{~cm})$ pitch in first, 36 to 39 in $(91$ to $99 \mathrm{~cm})$ in business and 32 to 34 in $(81$ to $86 \mathrm{~cm})$ in economy. Source: (Petrescu and Petrescu, 2012)

\section{Results and Discussion}

Boeing is an aeronautical and aerospace manufacturer.

Its head office is located in Chicago, Illinois. Its two largest plants are located in Wichita, Kansas and Everett, near Seattle.

This aircraft manufacturer specializes in the design of civil aircraft, but also in military aircraft, helicopters and in satellites and rockets with its Boeing Defense, Space and Security division.

In 2012, it ranks second in world military equipment sales.
The company was born on July 15,1916 , thanks to its two fathers William E. Boeing and George Conrad Westervelt and is named "B \& W".

Shortly afterwards, his name became "Pacific Aero Products" and finally "Boeing Airplane Company". In 1938, Boeing commissioned the 307 Stratoliner.

It was the first airplane with pressurized cabin; he was able to fly at a cruising altitude of 20,000 feet, so above most weather disturbances, making him the strongest aircraft in the Boeing fleet.

In response to the concentration move in the US defense industry initiated by its competitor Lockheed in 
1995, Boeing acquired Rockwell International's space and defense operations in August 1996 for \$3.2 billion.

Rockwell was the manufacturer of the seven US space shuttles (Enterprise, Pathfinder, Columbia, Atlantis, Endeavor, Discovery and Challenger).

Today in aviation very important are and the materials used (Aversa et al., 2016a; 2016b; 2016c; 2016d; 2016e; 2016f; 2016g; 2016h; 2016i; 2016j; 2016k; 2016l; 2016m; 2016n; 2016o, 2017a; 2017b; 2017c; 2017d; 2017e; Mirsayar et al., 2017).

Then, Boeing bought the number two defense equipment behind Lockheed Martin that is McDonnell Douglas, for \$3 billion in August 1997.

McDonnell Douglas was the manufacturer of the Delta launchers.

In 1999, the Boeing aircraft manufacturer sold 620 aircraft; in 2004, deliveries fell to 285 aircraft. It is now overtaken by its European competitor Airbus in orders since 2002 and in deliveries since 2004 (Source: Le Monde, 13 June 2005).

In 2005, in a record market, the company announces 1,005 orders (of which 569 B737, 235 B787 and 154 B777) surpassed again by Airbus of about fifty aircraft.

Boeing became the world's first aircraft manufacturer in 2006 with 1,044 orders versus 824 for Airbus. In 2008 , Boeing is the world leader in the defense sector.

In November 2016, Boeing announced a restructuring of its defense arm with the suppression of 500 positions, the closure of two plants in El Paso and Newington and the displacement of 2,000 employees.

\section{Conclusion}

Boeing is an aeronautical and aerospace manufacturer. Its head office is located in Chicago, Illinois. Its two largest plants are located in Wichita, Kansas and Everett, near Seattle.

This aircraft manufacturer specializes in the design of civil aircraft, but also in military aircraft, helicopters and in satellites and rockets with its Boeing Defense, Space and Security division.

\section{Author's Contributions}

All the authors contributed equally to prepare, develop and carry out this manuscript.

\section{Ethics}

Authors declare that are not ethical issues that may arise after the publication of this manuscript. This article is original and contains unpublished material.

\section{References}

Aversa, R., R.V.V. Petrescu, A. Apicella and F.I.T. Petrescu, 2017a. Nano-diamond hybrid materials for structural biomedical application. Am. J. Biochem. Biotechnol.

Aversa, R., R.V. Petrescu, B. Akash, R.B. Bucinell and J.M. Corchado et al., 2017b. Kinematics and forces to a new model forging manipulator. Am. J. Applied Sci., 14: 60-80.

Aversa, R., R.V. Petrescu, A. Apicella, I.T.F. Petrescu and J.K. Calautit et al., 2017c. Something about the $\mathrm{V}$ engines design. Am. J. Applied Sci., 14: 34-52.

Aversa, R., D. Parcesepe, R.V.V. Petrescu, F. Berto and G. Chen et al., 2017d. Process ability of bulk metallic glasses. Am. J. Applied Sci., 14: 294-301.

Aversa, R., R.V.V. Petrescu, B. Akash, R.B. Bucinell and J.M. Corchado et al., 2017e. Something about the balancing of thermal motors. Am. J. Eng. Applied Sci., 10: 200.217. DOI: 10.3844/ajeassp.2017.200.217

Aversa, R., F.I.T. Petrescu, R.V. Petrescu and A. Apicella, 2016a. Biomimetic FEA bone modeling for customized hybrid biological prostheses development. Am. J. Applied Sci., 13: 1060-1067. DOI: 10.3844/ajassp.2016.1060.1067

Aversa, R., D. Parcesepe, R.V. Petrescu, G. Chen and F.I.T. Petrescu et al., 2016b. Glassy amorphous metal injection molded induced morphological defects. Am. J. Applied Sci., 13: 1476-1482.

Aversa, R., R.V. Petrescu, F.I.T. Petrescu and A. Apicella, 2016c. Smart-factory: Optimization and process control of composite centrifuged pipes. Am. J. Applied Sci., 13: 1330-1341.

Aversa, R., F. Tamburrino, R.V. Petrescu, F.I.T. Petrescu and M. Artur et al., 2016d. Biomechanically inspired shape memory effect machines driven by muscle like acting NiTi alloys. Am. J. Applied Sci., 13: 1264-1271.

Aversa, R., E.M. Buzea, R.V. Petrescu, A. Apicella and M. Neacsa et al., 2016e. Present a mechatronic system having able to determine the concentration of carotenoids. Am. J. Eng. Applied Sci., 9: 1106-1111.

Aversa, R., R.V. Petrescu, R. Sorrentino, F.I.T. Petrescu and A. Apicella, 2016f. Hybrid ceramo-polymeric nanocomposite for biomimetic scaffolds design and preparation. Am. J. Eng. Applied Sci., 9: 1096-1105.

Aversa, R., V. Perrotta, R.V. Petrescu, C. Misiano and F.I.T. Petrescu et al., 2016g. From structural colors to super-hydrophobicity and achromatic transparent protective coatings: Ion plating plasma assisted $\mathrm{TiO}_{2}$ and $\mathrm{SiO}_{2}$ Nano-film deposition. Am. J. Eng. Applied Sci., 9: 1037-1045.

Aversa, R., R.V. Petrescu, F.I.T. Petrescu and A. Apicella, 2016h. Biomimetic and evolutionary design driven innovation in sustainable products development. Am. J. Eng. Applied Sci., 9: 1027-1036. 
Aversa, R., R.V. Petrescu, A. Apicella and F.I.T. Petrescu, 2016i. Mitochondria are naturally micro robots-a review. Am. J. Eng. Applied Sci., 9: 991-1002.

Aversa, R., R.V. Petrescu, A. Apicella and F.I.T. Petrescu, 2016j. We are addicted to vitamins $\mathrm{C}$ and E-A review. Am. J. Eng. Applied Sci., 9: 1003-1018.

Aversa, R., R.V. Petrescu, A. Apicella and F.I.T. Petrescu, 2016k. Physiologic human fluids and swelling behavior of hydrophilic biocompatible hybrid ceramo-polymeric materials. Am. J. Eng. Applied Sci., 9: 962-972.

Aversa, R., R.V. Petrescu, A. Apicella and F.I.T. Petrescu, 20161. One can slow down the aging through antioxidants. Am. J. Eng. Applied Sci., 9: 1112-1126.

Aversa, R., R.V. Petrescu, A. Apicella and F.I.T. Petrescu, $2016 \mathrm{~m}$. About homeopathy or «Similia similibus curentur $\gg$. Am. J. Eng. Applied Sci., 9: 1164-1172.

Aversa, R., R.V. Petrescu, A. Apicella and F.I.T. Petrescu, 2016n. The basic elements of life's. Am. J. Eng. Applied Sci., 9: 1189-1197.

Aversa, R., F.I.T. Petrescu, R.V. Petrescu and A. Apicella, 2016o. Flexible stem trabecular prostheses. Am. J. Eng. Applied Sci., 9: 1213-1221.

Boeing. http://www.boeing.com/
Boeing, From Wikipedia, the free encyclopedia. https://en.wikipedia.org/wiki/Boeing

Lockheed Martin F-22 Raptor, From Wikipedia, the free encyclopedia. https://en.wikipedia.org/wiki/Lockheed_Martin_F22_Raptor

Mirsayar, M.M., V.A. Joneidi, R.V.V. Petrescu, F.I.T. Petrescu and F. Berto, 2017 Extended MTSN criterion for fracture analysis of soda lime glass. Eng. Fracture Mechan., 178: 50-59. DOI: 10.1016/j.engfracmech.2017.04.018

Petrescu, R.V. and F.I. Petrescu, 2013a. Lockheed Martin. 1st Edn., CreateSpace, pp: 114.

Petrescu, R.V. and F.I. Petrescu, 2013b. Northrop. 1st Edn., CreateSpace, pp: 96.

Petrescu, R.V. and F.I. Petrescu, 2013c. The Aviation History or new Aircraft I Color. 1st Edn., CreateSpace, pp: 292.

Petrescu, F.I. and R.V. Petrescu, 2012. New Aircraft II. 1st Edn., Books On Demand, pp: 138.

Petrescu, F.I. and R.V. Petrescu, 2011. Memories about Flight. 1st Edn., CreateSpace, pp: 652. 